\title{
Advances in Tetrapyrrolic Chemistry over 2013-2017 of Research group Headed by Full Member of RAS A. Yu. Tsivadze: Highlights on the Occasion of his Anniversary
}

\author{
Yulia G. Gorbunova, ${ }^{\mathrm{a}, \mathrm{b}}$ Alexander Martynov, ${ }^{a}$ Pavel Stuzhin, ${ }^{\mathrm{c}}$ and Oskar I. Koifman \\ ${ }^{a}$ A.N. Frumkin Institute of Physical Chemistry and Electrochemistry RAS, 119071 Moscow, Russia \\ ${ }^{\mathrm{b}}$ N.S. Kurnakov Institute of General and Inorganic Chemistry RAS, 119991 Moscow, Russia \\ ${ }^{\mathrm{c}}$ Research Institute of Macroheterocyclic Compounds, Ivanovo State University of Chemistry and Technology, 153000 \\ Ivanovo, Russia \\ @Corresponding authorE-mail: yulia@igic.ras.ru
}

This brief review summarizes and highlights some of scientific advances in the field of porphyrin/phthalocyanine chemistry, which were achieved under the leadership of Full member of Russian Academy of Sciences, Professor Aslan Tsivadze over 2013-2017.

Keywords: Porphyrins, phthalocyanines, supramolecular chemistry, photophysics, molecular switchers.

\section{Обзор Аостижений в области химии тетрапиррольных соединений, полученных в группе академика А. Ю. ЦиваАзе за период 2013-2017 гг.}

\author{
Ю. Г. Горбунова, ${ }_{1}^{\text {a,b@ }}$ А. Г. Мартынов, ${ }^{a}$ П. А. Стужин, ${ }_{1}{ }^{c}$ О. И. Койфман ${ }^{\mathrm{c}}$ \\ ${ }^{\mathrm{a}}$ Институт физической химии и электрохимии им. А.Н. Фрумкина РАН, 119071 Москва, Россия \\ ${ }^{\mathrm{b}}$ Институт общей и неорганической химии им. Н.С. Курнакова РАН, 119991 Москва, Россия \\ 'НИИ химии макрогетероциклических соединений, Ивановский государственный химико-технологический \\ университет, 153000 Иваново, Россия \\ ${ }^{\circledR}$ E-mail: yulia@igic.ras.ru
}

\begin{abstract}
В кратком обзоре приведены достижения в области химии тетрапиррольных соединений, полученные в группе академика РАН А.Ю. Цивадзе за период 2013-2017 г2.
\end{abstract}

Ключевые слова: Порфирины, фталоцианины, супрамолекулярная химия, фотофизика, молекулярные переключатели. 
Dear Readers!

This issue of the "Macroheterocycles" contains several papers dedicated to Professor Aslan Yusupovich Tsivadze, full member of Russian Academy of Sciences, President of Mendeleev Russian Chemical Society, scientific leader of A.N. Frumkin Institute of Physical Chemistry and electrochemistry of Russian Academy of Sciences on the occasion of his 75 th birthday.

The detailed summary about biography and scientific achievements of Professor Tsivadze was presented 5 years ago ${ }^{[1,2]}$ Thus, this welcoming review summarizes and highlights some of scientific advances in the field of macroheterocycles, mainly in the field of porphyrin/phthalocyanine chemistry, which were achieved under the leadership of Aslan Tsivadze over 2013-2017. Recent selected results will be presented in following fields:

- New synthetic approaches towards functionalized porphyrins and phthalocyanines

- Synthesis and characterization of novel complexes with tetrapyrrolic ligands

- Phosphorylated porphyrins: from synthesis to materials

- Molecular switchers and receptors

- Photophysical and nonlinear optical properties of tetrapyrrolic compounds

Graphical abstracts of selected publications are used as illustrations of the presented researches.

\section{New synthetic approaches towards functionalized porphyrins and phthalocyanines}

Series of substituted phthalonitriles were obtained by means of Pd-catalyzed cyanation reaction in high yields. Analysis of the obtained results together with previously reported data concerning transition metal catalyzed synthesis of phthalonitriles and analogues reveals advantages of each of these methods in comparison with classical approaches - ammonolysis/dehydratation and RosenmundBraun cyanation (Figure 1). ${ }^{[3]}$

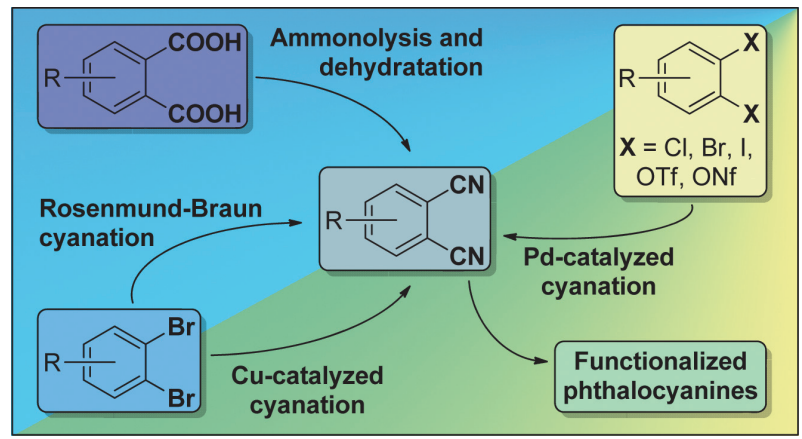

Figure 1. Modern synthetic approaches to phthalonitriles with special emphasis on transition-metal catalyzed cyanation reactions. ${ }^{[3]}$

Synthesis of low-symmetry phthalocyanine analogue annelated with phenanthroline unit was performed, the electronic structure and $\mathrm{NH}$-tautomerism were characterized by ${ }^{1} \mathrm{H}$ and ${ }^{13} \mathrm{C}$ NMR spectroscopy and TDDFT calculations (Figure 2). ${ }^{[4]}$

Synthetic approaches towards meso-RO-appended ( $\mathrm{R}=$ alkyl, aryl) porphyrins bearing one or two OR substituents at the tetrapyrrolic macrocycle were proposed starting from meso-brominated porphyrins using a $\mathrm{S}_{\mathrm{N}} \mathrm{Ar}$ reaction. Moreover, monofunctionalization of porphyrins according to $\mathrm{S}_{\mathrm{N}}$ Ar reaction was used as a key step for the synthesis of rarely explored unsymmetrical porphyrinyl alkyl ethers (Figure 3).$^{[5]}$ This research was carried out in the framework of the International Associated French-Russian Laboratory of Macrocyclic Systems and Related Materials (LIA

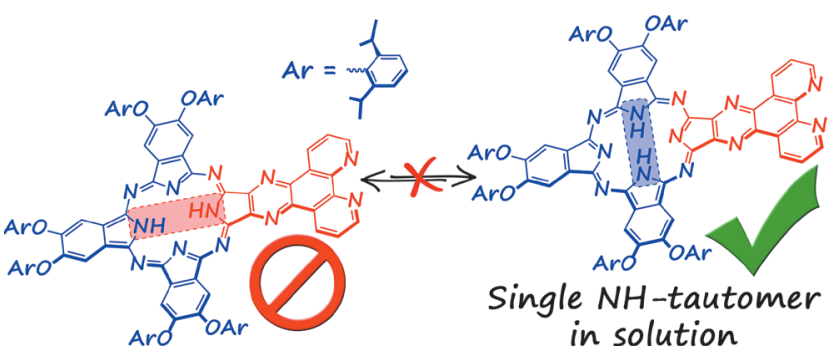

Figure 2. Electronic structure and NH-tautomerism of a novel metal-free phenanthroline-annelated phthalocyanine. ${ }^{[4]}$

LAMREM) together with Prof. Roger Guilard and Dr. Alla Lemeune group (University of Burgundy, France).

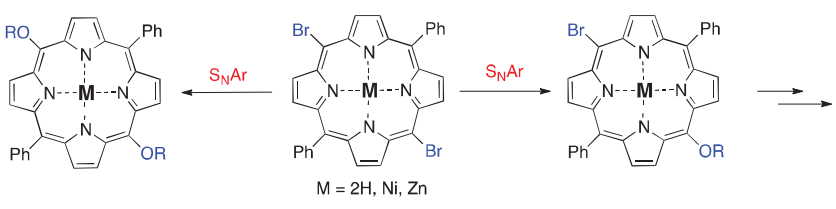

Figure 3. Insights into the synthesis and the solution behavior of meso-aryloxy and alkoxy substituted porphyrins..$^{[5]}$

The synthesis of functionalized porphyrins and their conjugates from meso-tetraarylporphyrins through the acylation and the oxidation of $\beta$-aminoporphyrins was investigated (Figure 4). Mildness and usefulness of this methodol-

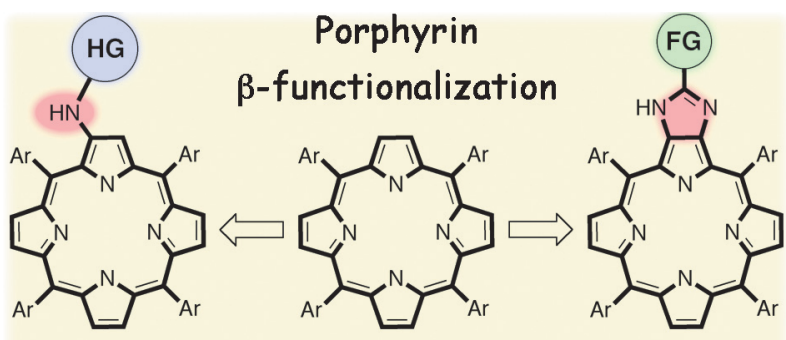

$F G=$ functional group; $H G=$ hydrophilic group

Figure 4. On the synthesis of functionalized porphyrins and porphyrin conjugates via $\beta$-aminoporphyrins. ${ }^{[6]}$ 
ogy were illustrated by several examples including the synthesis of porphyrins bearing receptor groups and water-solubilizing moieties ${ }^{[6]}$ (LAMREM).

A strategy for the post-functionalization of readily accessible meso-formylporphyrins affording meso-(2-imidazolyl)porphyrins, containing substituents at the 4,5-positions of the imidazole fragment was developed (Figure 5). This methodology was used to prepare a set of representatives of this new type of substituted porphyrins. ${ }^{[7]}$

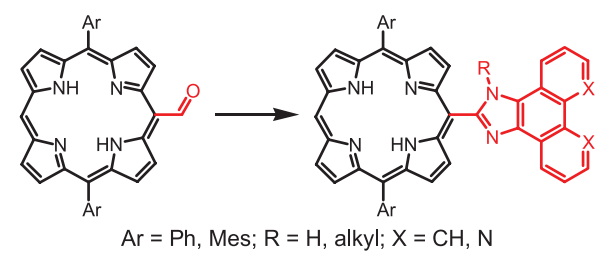

Figure 5. New approach for post-functionalization of mesoformylporphyrins. ${ }^{[7]}$

Suzuki-Miyaura cross-coupling reaction has been used for the synthesis of tricyclic architectures based on trans$\mathrm{A}_{2} \mathrm{~B}_{2}$-porphyrins and bisaminal-protected polyazamacrocycles which are linked directly or by a $p$-phenylene spacer (Figure 6). This modular approach allowed the synthesis of ligands with various substituted porphyrin macrocycles and bisaminal-protected tetraazamacrocycles possessing different cavity sizes. These molecules can be assembled into dimers using a DABCO linker. Deprotection of these compounds afforded porphyrin-bis(polyazamacrocycle) triads $^{[8]}$ (LAMREM).

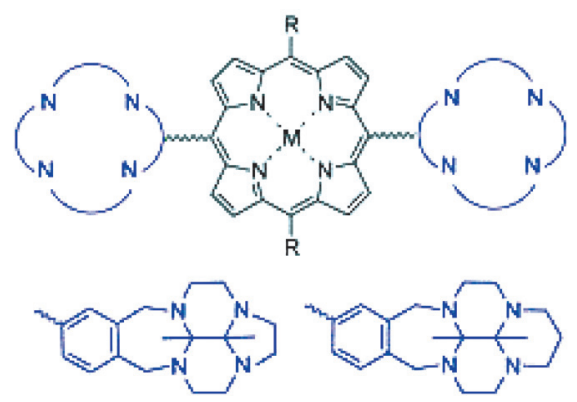

Figure 6. Synthesis of porphyrin-bis(polyazamacrocycle) triads via Suzuki coupling reaction. ${ }^{[8]}$

\section{Synthesis and characterization of novel complexes with tetrapyrrolic ligands}

A convenient synthetic approach towards alkyloxy substituted (24-crown-8)-linked dimeric phthalocyanines was developed (Figure 7).

The Mg-templated statistical condensation of the mixture of phthalonitriles was found to be the most efficient and versatile pathway. Demetalation of the resulting $\mathrm{Mg}$ phthalocyanines afforded metal-free (24-crown-8)-linked dimeric phthalocyanines as versatile precursors for prepara-

\section{Dimeric crown-linked phthalocyanines - perspective pincer-type receptors}

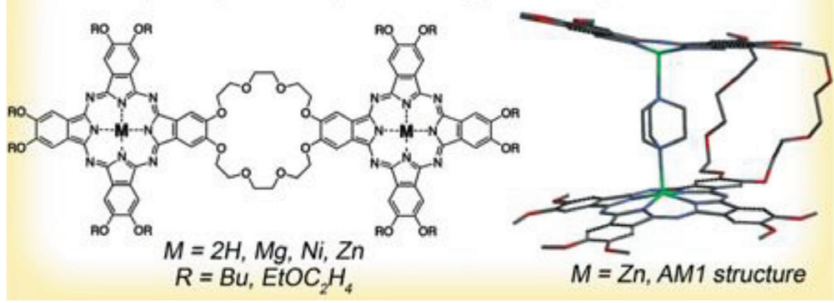

Figure 7. (24-Crown-8)-linked dimeric phthalocyanines and their metal complexes. ${ }^{[9]}$

tion of other metal complexes. The dimeric linked phthalocyanine metal complexes may become convenient receptors for recognition of ditopic guests. ${ }^{[9]}$

A $\mu$-carbido diruthenium(IV) phthalocyanine complex was prepared for the first time from the free-base octabutoxyphthalocyanine by direct metalation with $\mathrm{Ru}_{3}(\mathrm{CO})_{12}$ (Figure 8). The first examples of the catalytic activity of $\mathrm{Ru}^{\mathrm{IV}}$ binuclear phthalocyanines were demonstrated by the cyclopropanation of aromatic olefins and carbene insertion into the $\mathrm{N}-\mathrm{H}$ bonds of aromatic or aliphatic amines with turnover numbers of $680-1000$ and 580-1000, respectively. ${ }^{[10]}$ This research was performed together with group of Prof. Alexander Sorokin (IRCELYON, France).

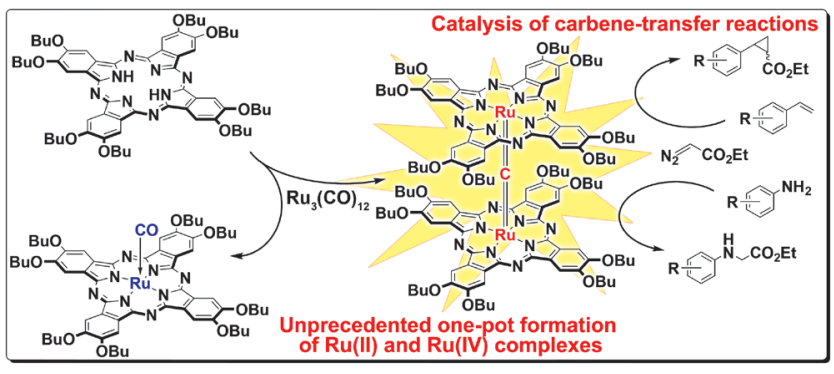

Figure 8. Unexpected formation of a $\mu$-carbido diruthenium(IV) complex during the metalation of phthalocyanine with $\mathrm{Ru}_{3}(\mathrm{CO})_{12}$ and its catalytic activity in carbene transfer reactions. ${ }^{[10]}$

The synthesis and characterization of heteronuclear crown-substituted trisphthalocyaninates was reported (Figure 9). The solid-state structure of complexes was studied by single-crystal X-ray diffraction analysis, providing therefore a structural model for the assignment and analysis of ${ }^{1} \mathrm{H}$ NMR spectra of the complexes, which is strongly affected by the presence of paramagnetic lanthanide ions. ${ }^{[1]}$

Magnetic measurements on the homonuclear $\mathrm{Tb}^{\mathrm{III}}$ trisphthalocyaninate displayed non-negligible ferromagnetic coupling between magnetic ions, eliciting a high zerofield energetic barrier to the magnetic relaxation, while the heteronuclear $\mathrm{Tb}^{\mathrm{II}} / \mathrm{Y}^{\mathrm{III}}$ complexes displayed singleion field-induced slow relaxation of the magnetization (Figure 10). ${ }^{[12]}$ This research was performed together with group of Dr. Muralee Murugesu (University of Ottawa, Canada). 


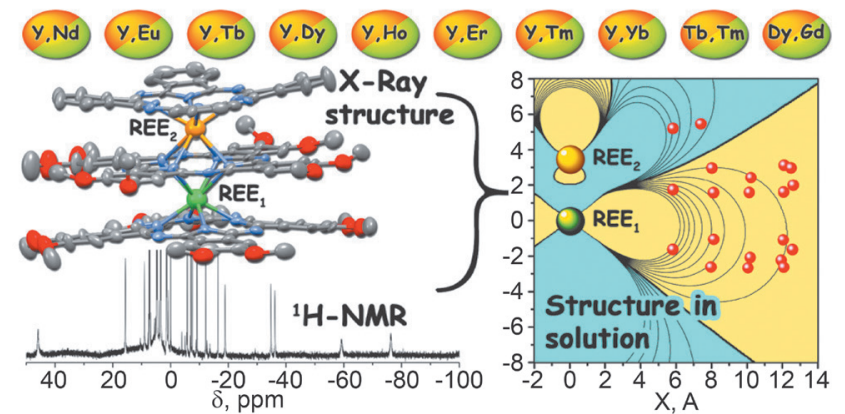

Figure 9. Determination of the structural parameters of heteronuclear (phthalocyaninato)bis(crownphthalo-cyaninato) lanthanide(III) triple-deckers in solution by simultaneous analysis of NMR and single-crystal X-ray data. ${ }^{[1]}$

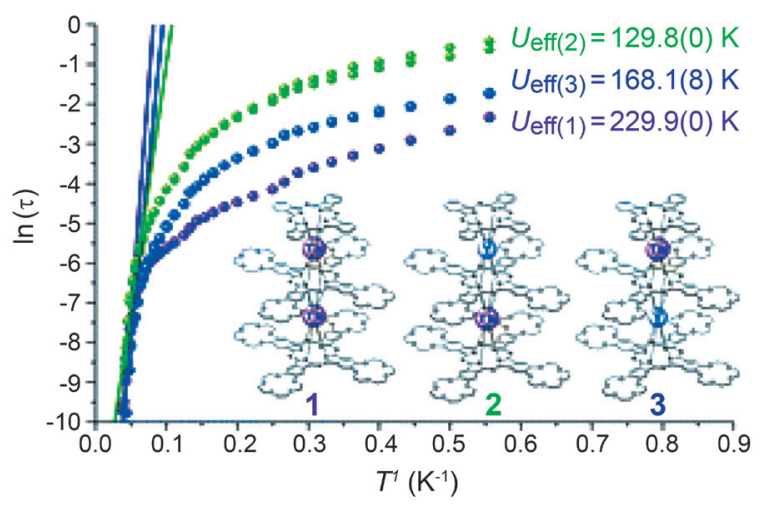

Figure 10. Impact of the coordination environment on the magnetic properties of single-molecule magnets based on homo- and hetero-dinuclear terbium(III) heteroleptic tris(crownphthalocyaninate). ${ }^{[12]}$

\section{Phosphorylated porphyrins: from synthesis to materials}

The research on phosphorylated porphyrins (Figure 11) was carried out in the framework of the International Associated French-Russian Laboratory of Macrocyclic Systems and Related Materials (LIA LAMREM) together with Prof. Roger Guilard and Dr. Alla Lemeune group (University of Burgundy, France) and Prof. Karl Kadish (Houston University, USA).

A two-step reaction sequence for accessing meso(dialkoxyphosphoryl)porphyrins from readily available trans- $\mathrm{A}_{2}$-type porphyrins was developed. This approach involves bromination and subsequent palladium-catalyzed phosphonylation (Figure 12). These compounds, being air-stable and soluble in most organic solvents, are valuable synthetic intermediates because they can be readily transformed into functionalized trans- $\mathrm{A}_{2} \mathrm{BC}$ type porphyrins through regioselective functionalization at the unsubstituted meso-position of the macrocycle. Therefore, this approach offers considerable promise for application to the synthesis of trans- $\mathrm{A}_{2} \mathrm{BC}$-type porphyrins,

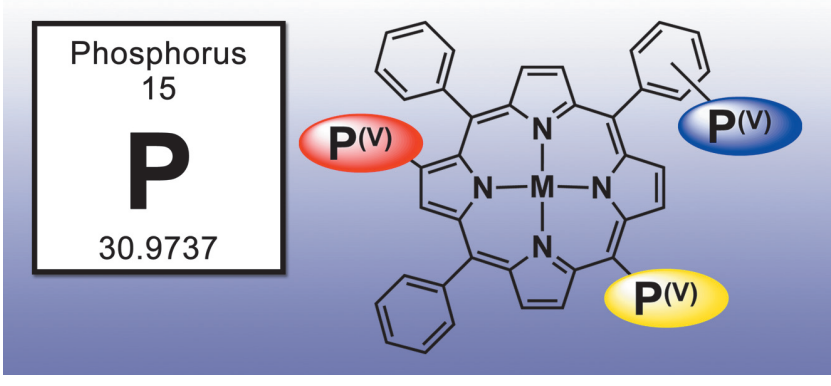

Figure 11. Survey of synthetic routes towards phosphorus substituted porphyrins. ${ }^{[14]}$

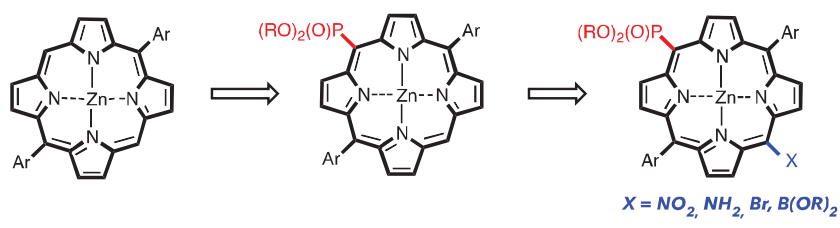

Figure 12. General and scalable approach to $\mathrm{A}_{2} \mathrm{~B}$ - and $\mathrm{A}_{2} \mathrm{BC}$-type porphyrin phosphonate diesters. ${ }^{[13]}$

including water-soluble derivatives, push-pull chromophores and bis(porphyrin)s. ${ }^{[13,14]}$

Two series of diphosphoryl-substituted porphyrins were synthesized and characterized by electrochemistry and spectroelectrochemistry. The free-base and five metalated porphyrins with nonredox active centers undergo two ring-centered oxidations and two ring-centered reductions, the latter of which is followed by a chemical reaction of the porphyrin dianion to give an anionic phlorin product (Figure 13). The phlorin anion is electroactive and can be reoxidized by two electrons to give back the starting porphyrin, or it can be reversibly reduced by one electron at more negative potentials to give a phlorin dianion. ${ }^{[15]}$

Single-crystal X-Ray diffraction analysis was widely used for characterization of newly synthesized mesophosphorylated porphyrins to study the processes of their self-assembly in crystalline state. The insight into the crystal

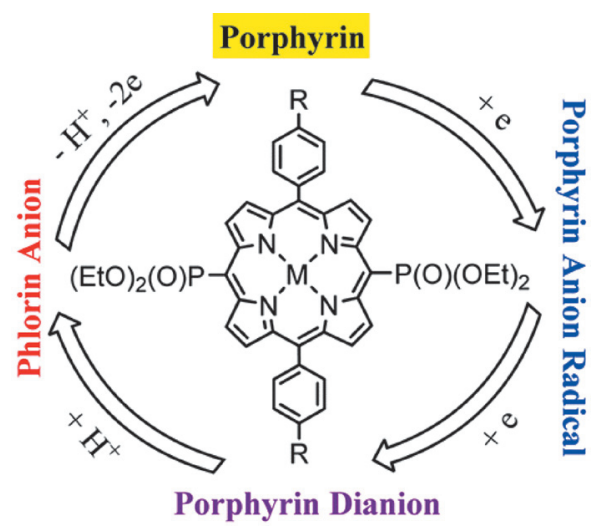

Figure 13. Electrochemical and spectroelectrochemical studies of diphosphorylated metalloporphyrins. Generation of a phlorin anion product. ${ }^{[15]}$ 
packing of phosphorylated porphyrins can be achieved in terms of topological analysis of intermolecular interaction energies (Figure 14). ${ }^{[16]}$

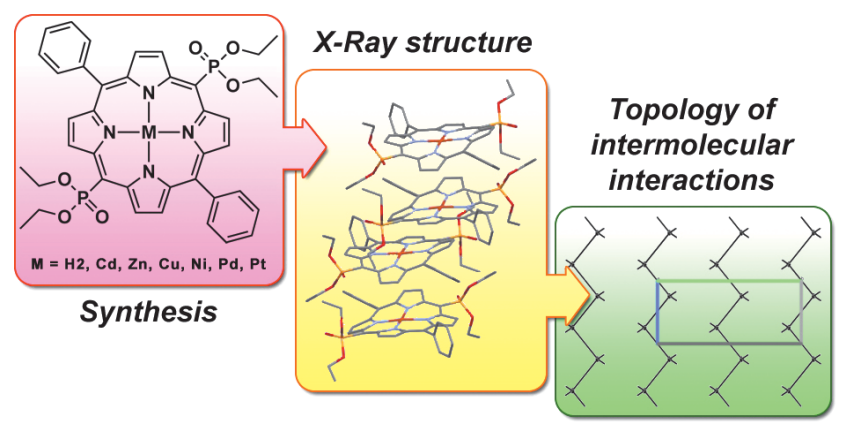

Figure 14. Insights into the crystal packing of phosphorylporphyrins based on the topology of their intermolecular interaction energies. ${ }^{[16]}$

Depending on the nature of metal, various types of crystal packing can be obtained. For example, in the case of copper(II) bis-meso-phosphorylated porphyrin the unusual formation of a stable 2D coordination network was observed (Figure 15). ${ }^{[17]}$

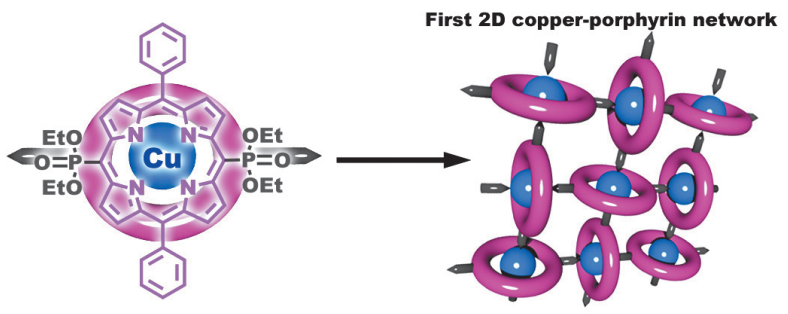

Figure 15. Unusual formation of a stable 2D copper porphyrin network. ${ }^{[17]}$

A novel series of one-dimensional homo- and heterometallic coordination polymers was prepared from planar and nonplanar metallo(diphosphoryl)porphyrinates and dicopper(II) tetra-pivalate paddle-wheel complex (Figure 16). In these polymers, paddle-wheel dicopper(II) units

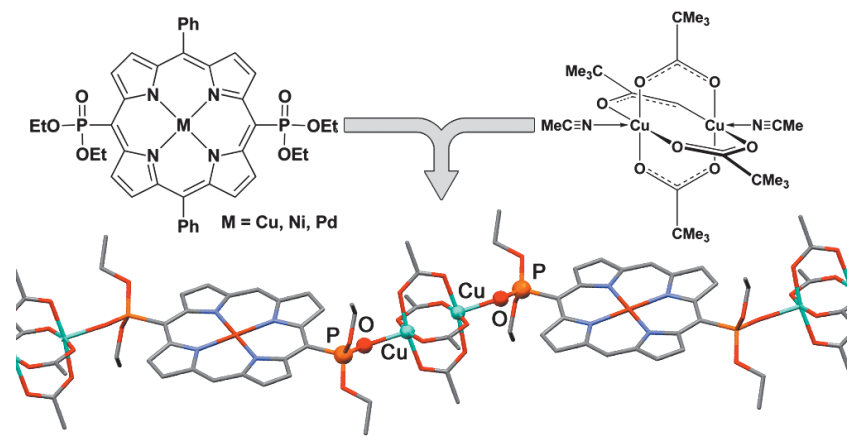

Figure 16. Supramolecular assembly of organophosphonate diesters using paddle-wheel complexes: first examples in porphyrin series. ${ }^{[18]}$

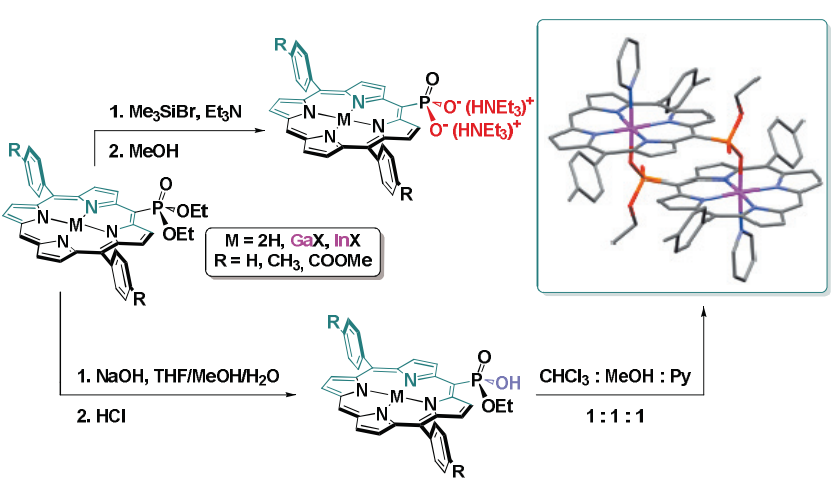

Figure 17. Gallium(III) and indium(III) complexes with mesomonophosphorylated porphyrins: synthesis and structure. a first example of dimers formed by the self-assembly of mesoporphyrinylphosphonic acid monoester. ${ }^{[19]}$

are assembled with porphyrin donors in a 1:1 ratio through axial $\mathrm{Cu}-\mathrm{O}=\mathrm{P}$ coordination. ${ }^{[18]}$

The synthesis and structural characterization of a series of gallium(III) and indium(III) mesomono(diethoxyphosphoryl)-porphyrins bearing different peripheral substituents as well as the corresponding monoesters and phosphonic acids was reported (Figure 17). This work described the first example of the X-ray structure of a self-assembled dimer formed via strong binding between the oxygen atom of the phosphorus substituent and the gallium(III) cations of adjacent porphyrin molecules. ${ }^{[19]}$

\section{Molecular switchers and receptors}

Synthesis and supramolecular chemistry of crownsubstituted phthalocyanines is studied in the group of Aslan Tsivadze for more than 20 years. ${ }^{[20]}$ Investigation of their cation-induced self-assembly emphasizes the importance of cooperative effects in supramolecular chemistry of these polytopic receptors (Figure 18). ${ }^{[21]}$

For the first time single-crystal X-ray diffraction analysis of supramolecular cation-induced dimer formed by crown-phthalocyanine was reported on the example of $\quad[(\mu$-oxo)bis(tetra-15-crown-5-phthalocyaninato)(nico-

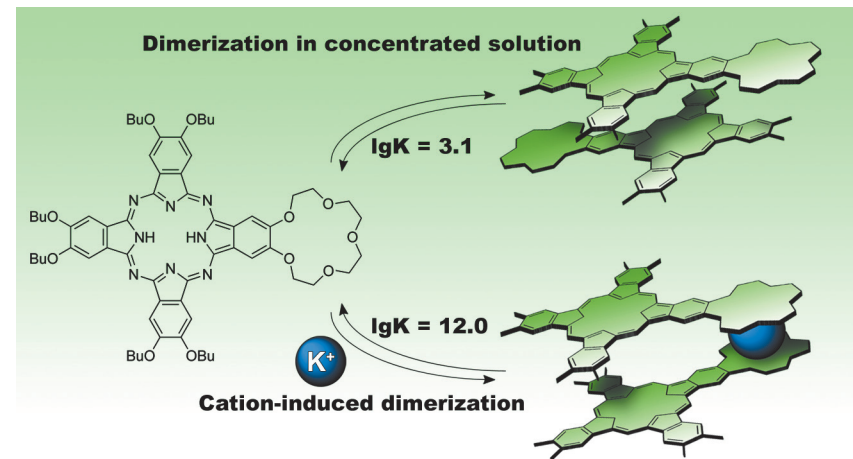

Figure 18. Behaviour of low-symmetry crown-phthalocyanine in solution: concentration aggregation $v s$. cation-induced assembly. $^{[21]}$ 


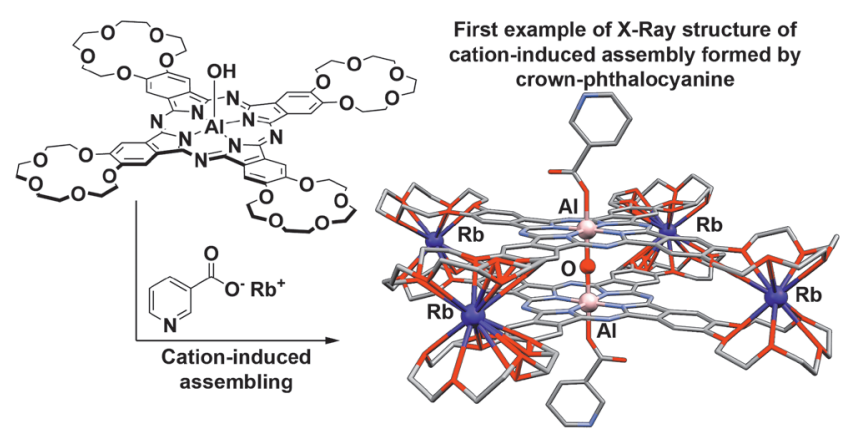

Figure 19. Cation-induced dimerization of crown-substituted phthalocyanines by complexation with rubidium nicotinate as revealed by X-ray structural data. ${ }^{[22]}$

tinato)aluminum(III)]-tetra(rubidium) (Figure 19). X-Ray diffraction study of this complex demonstrated that two molecules of the aluminum crown-phthalocyaninate nicotinate are connected through an $\mathrm{Al}-\mathrm{O}-\mathrm{Al}$ bridge supported by sandwiching of crown ether moieties by $\mathrm{Rb}^{+}$cations. ${ }^{[22]}$

On the example of indium(III) crown-phthalocyaninate it was demonstrated that the formation of similar supramolecular dimers has profound effects on photophysical properties of phthalocyanines, particularly significant enhancement of complex photostability was observed (Figure 20). ${ }^{[23]}$

Reversible formation of supramolecular cation-induced dimers was used as a powerful tool to control aggregation of new class of panchromatic compounds - crown-substituted oxanthrenocyanines (Figure 21). ${ }^{[2]}$ Peculiarities of UVVis spectral properties of these compounds were interpreted by TDDFT calculations and MCD spectroscopy. ${ }^{[25]}$

Novel "molecular chameleons", namely nonperipherally substituted crown-oxanthrenocyanines were synthesized (Figure 22). Both aggregation of molecules and their participation in an acid-base equilibrium strongly alter their optical properties. Thus, the absorption of complexes can be reversibly tuned from 686 up to $1028 \mathrm{~nm}$ by either the cation-induced formation

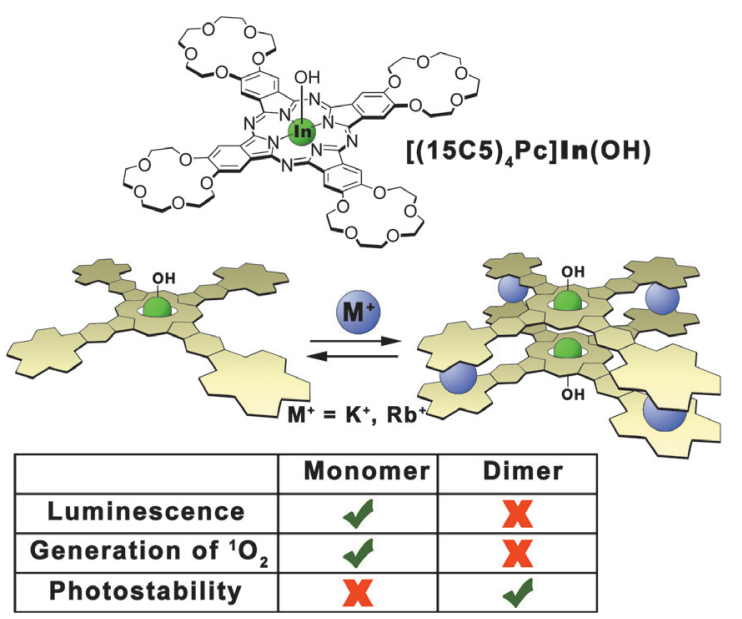

Figure 20. Synthesis, spectral properties, cation-induced dimerization and photochemical stability of tetra-(15-crown-5)phthalocyaninatoindium(III). ${ }^{[23]}$

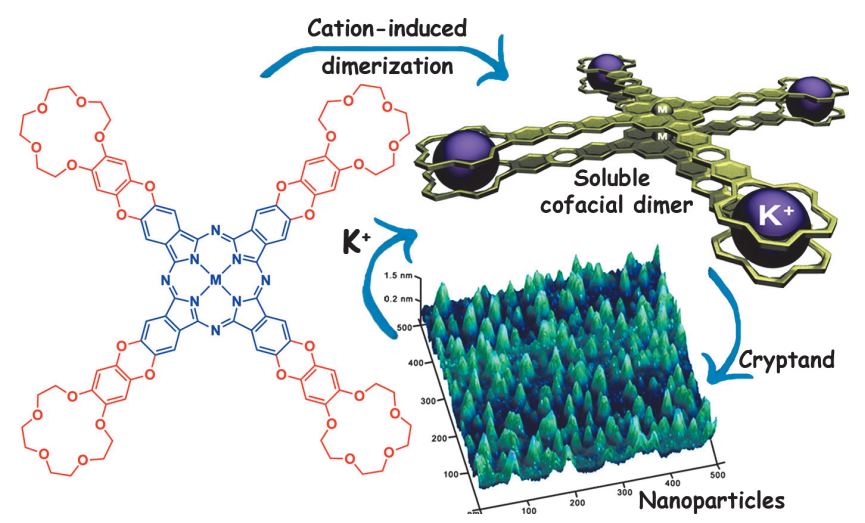

Figure 21. Design of UV-Vis-NIR panchromatic crownphthalocyanines with controllable aggregation. ${ }^{[2]}$

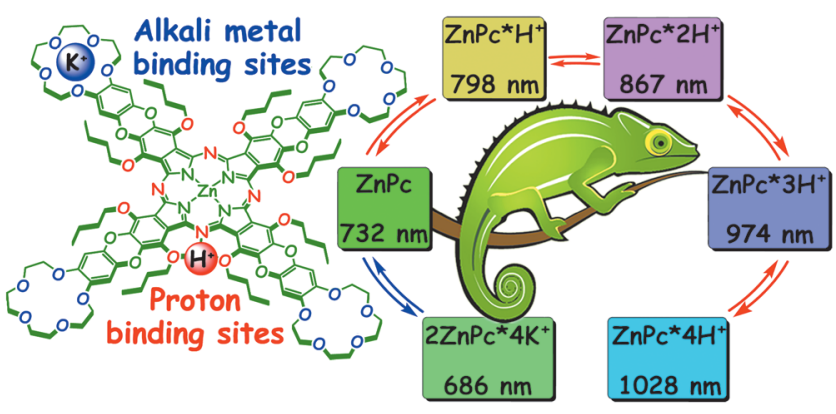

Figure 22. A molecular chameleon: reversible $\mathrm{pH}$ - and cationinduced control of the optical properties of phthalocyanine-based complexes in the visible and near-infrared spectral ranges. ${ }^{[26]}$

of supramolecular dimers or the protonation of meso-N atoms of oxanthrenocyanines. ${ }^{[26]}$

Another representative of the molecular zoo - octopus-like receptor based on phthalocyanines with flexible benzylated diethyleneglycol groups was used as hosts to bind fullerene guests (Figure 23). The binding was studied by spectrophotometric and fluorescence titration. It was shown that the molecule can discriminate $\mathrm{C}_{60}$ and $\mathrm{C}_{70}$

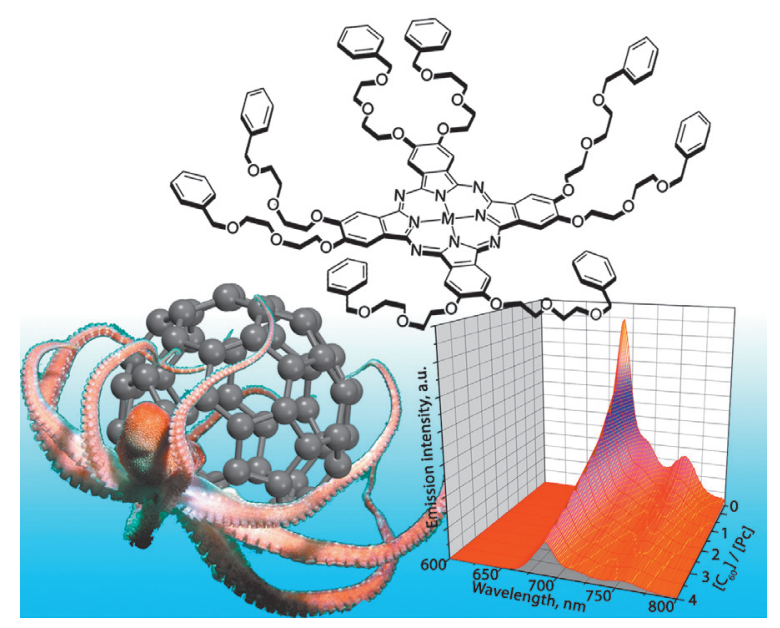

Figure 23. New octopus-like phthalocyanines as fullerene receptors: synthesis and photophysical investigation. ${ }^{[27]}$ 


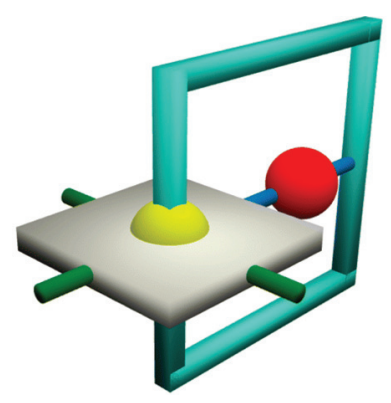

Figure 24. Phosphorus(V) porphyrin-based molecular turnstiles. ${ }^{[28]}$

molecules, which was confirmed by quantum-chemical calculations. $^{[27]}$

A cationic molecular turnstile based on a $\mathrm{P}(\mathrm{V})$ porphyrin backbone bearing a pyridyl unit at the meso-position and a handle, equipped with a pyridyl moiety, connected to the porphyrin through $\mathrm{P}-\mathrm{O}$ bonds was designed together with group of Prof. Wais Hosseini group from Strasbourg University, France (Figure 24). The solution dynamic behavior of the turnstile was investigated by ${ }^{1} \mathrm{H}$ NMR techniques. The reversible switching between the open and the closed states of the turnstile was achieved using $\mathrm{Ag}^{+}$or $\mathrm{H}^{+}$as external effector. ${ }^{[28]}$

New class of clamshell-type lanthanide diphthalocyaninates bearing 24-crown-8 linking fragment are synthesized and characterized (Figure 25). A strong solvatochromism of the complexes, allowing switching the widerange panchromatic absorption in polar solvents, is demonstrated by means of UV-Vis and NMR spectroscopies and attributed to solvent-induced changing of sandwich conformations. ${ }^{[29]}$

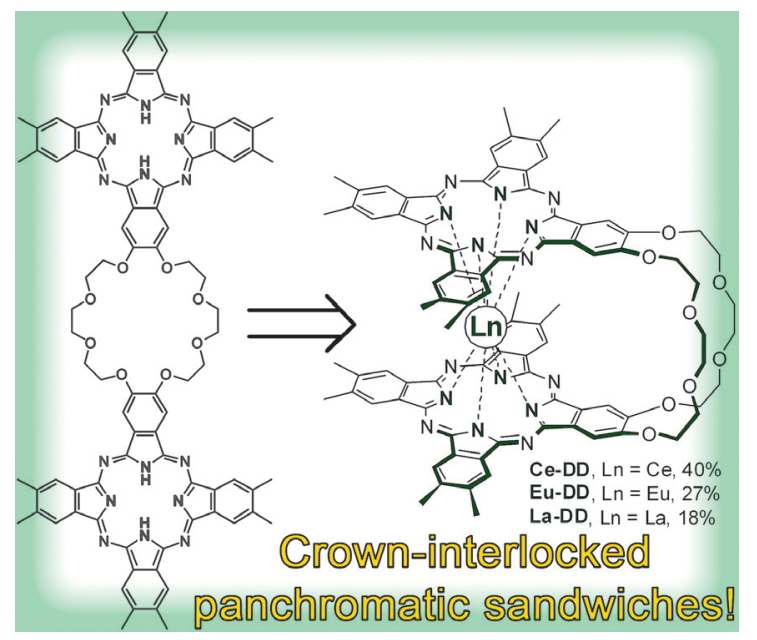

Figure 25. Crown-interlocked lanthanide diphthalocyaninates with switchable panchromatic absorption. ${ }^{[2]}$

The novel phenomenon orientation-induced redox isomerism in a Langmuir monolayer was revealed in the case of cerium bis[tetra(15-crown-5)phthalocyaninate] which occurs due to reversible intramolecular electron

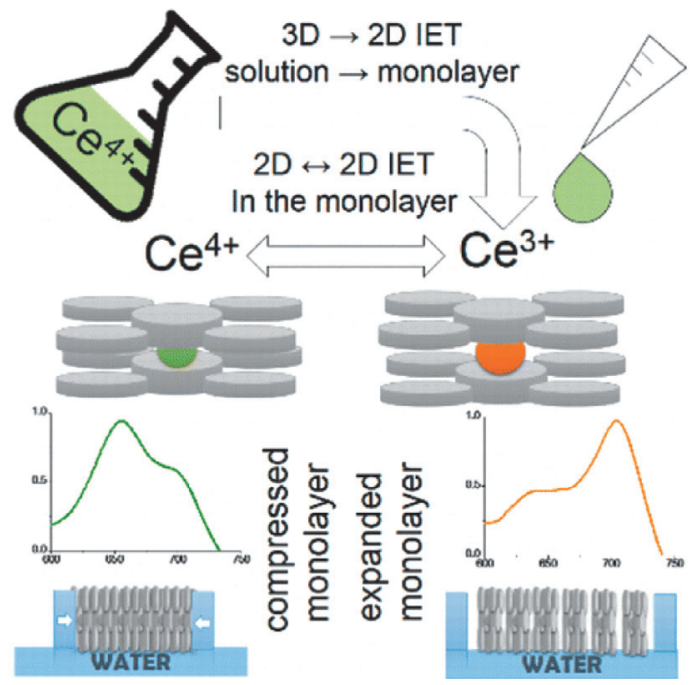

Figure 26. Orientation-induced redox isomerism in planar supramolecular systems. ${ }^{[30]}$

transfer between the electronic system of phthalocyanine to the $4 f$-orbital of cerium atom (together with group of Prof. V. Arslanov, IPCE RAS) (Figure 26). The understanding of this reversible IET mechanism is especially important due to possible applications of such redox-isomeric systems in the development of nanoscale multibit information storage devices. ${ }^{[30]}$

\section{Photophysical and nonlinear optical properties of tetrapyrrolic compounds}

Rich and interesting photophysical behavior of phthalocyanines affords their wide application in elaboration of optical materials and devices, including fabrication of materials for nonlinear optics. The later research was made in the collaboration with Prof. Tebello Nyokong group (Rhodes University, Grahamstown, South Africa) and group of Prof. A. Vannikov (IPCE RAS).

It was demonstrated, that the $\mathrm{A}_{3} \mathrm{~B}$-type phthalocyanine ligand, bearing two [2'-(2''-hydroxyethoxy)ethoxy]-

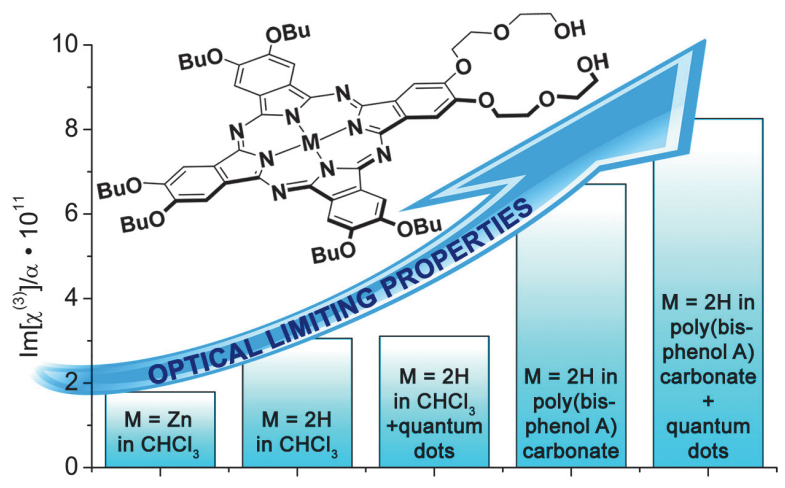

Figure 27. Improvement of nonlinear optical properties of phthalocyanine bearing diethyleneglycole chains: Influence of symmetry lowering $v s$. heavy atom effect. ${ }^{[31]}$ 


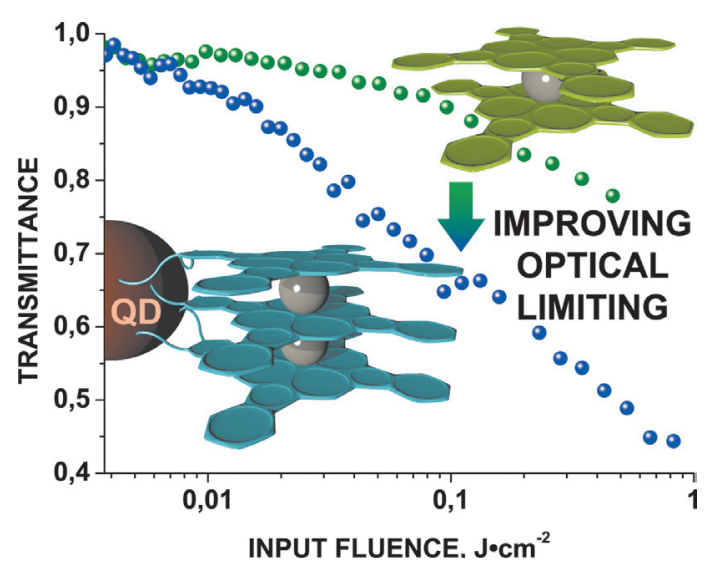

Figure 28. First example of nonlinear optical materials based on nanoconjugates of sandwich phthalocyanines with quantum dots. ${ }^{[32]}$

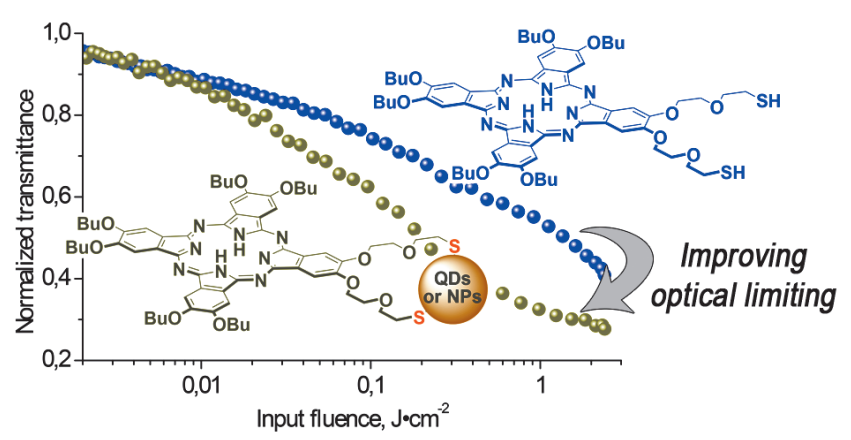

Figure 29. Optical limiters with improved performance based on nanoconjugates of thiol substituted phthalocyanine with CdSe quantum dots and Ag nanoparticles. ${ }^{[33]}$

substituents and six solubilizing $n$-butoxy groups reveals good OL properties, exceeding the ones of symmetrical octa- $n$-butoxyphthalocyanine (Figure 27). ${ }^{[31]}$ Moreover, this ligand was found to be a convenient platform for preparation of sandwich double- and triple-decker complexes, revealing superior OL characteristics which can be further improved by their grafting on the surface of quantum dots modified with mercaptosuccinic acid (Figure 28). ${ }^{[32]}$ Substitution of $\mathrm{OH}$-groups in the starting phthalocyanine with thiols afforded molecule, which could be directly grafted onto the surface of quantum dots and silver nanoparticles (Figure 29). ${ }^{[33]}$

The crucial role of self-assembly in nonlinear optical properties of phthalocyanines was demonstrated on the example of polymeric composites based on crownsubstituted ruthenium phthalocyaninate with axially coordinated pyrazine ligands (Figure 30). ${ }^{[34]}$

The ability of tetrapyrrolic macrocycles to promote generation of singlet oxygen was used for the elaboration of photosensitizers for photodynamic therapy. Bilayer lipid membares were used as models of cell surfaces for the tests of photodynamic activity of phthalocyanines using voltage-sensitive styryl dyes as singlet oxygen targets (Figure 31). ${ }^{[35]}$

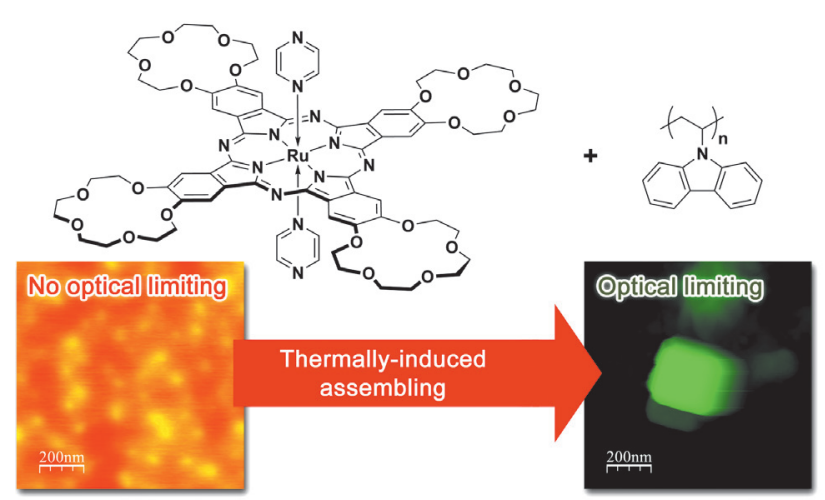

Figure 30. The crucial role of self-assembly in nonlinear optical properties of polymeric composites based on crown-substituted ruthenium phthalocyaninate. ${ }^{[34]}$

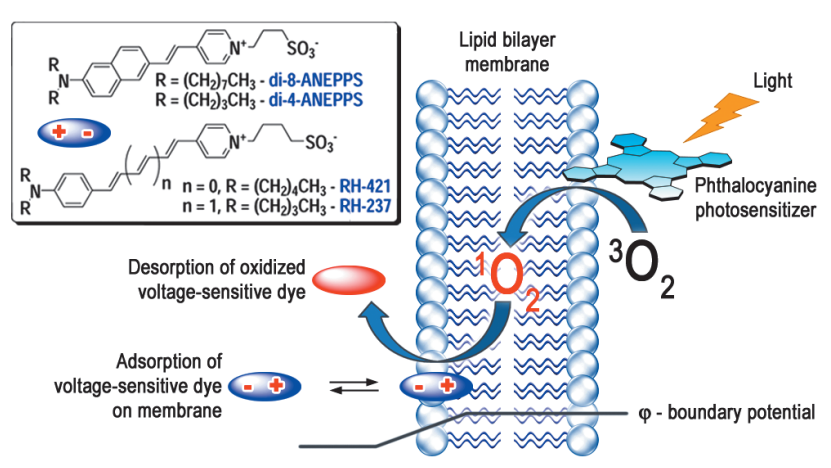

Figure 31. Voltage-sensitive styryl dyes as singlet oxygen targets on the surface of bilayer lipid membrane. ${ }^{[35]}$

Photosensitizing and emission properties of $\mathrm{P}(\mathrm{V})$ porphyrins were studied. It was demonstrated that the nature of the axial ligands, occupying the apical position on the $\mathrm{P}$ centre adopting an octahedral coordination geometry, strongly influences singlet oxygen generation and charge transfer and allows switching between the two processes (Figure 32). ${ }^{[36]}$

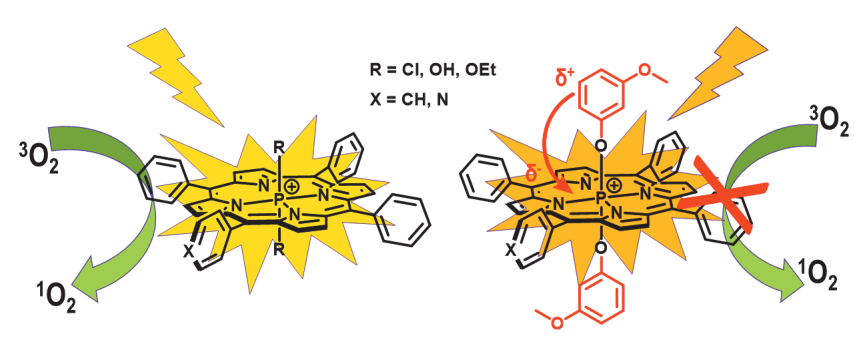

Figure 32. Tuning photochemical properties of phosphorus(V) porphyrin photosensitizers. ${ }^{[36]}$

Other research of the group (Figure 33) devoted to porphyrin and phthalocyanine chemistry are presented in following papers. ${ }^{[37-47]}$ 


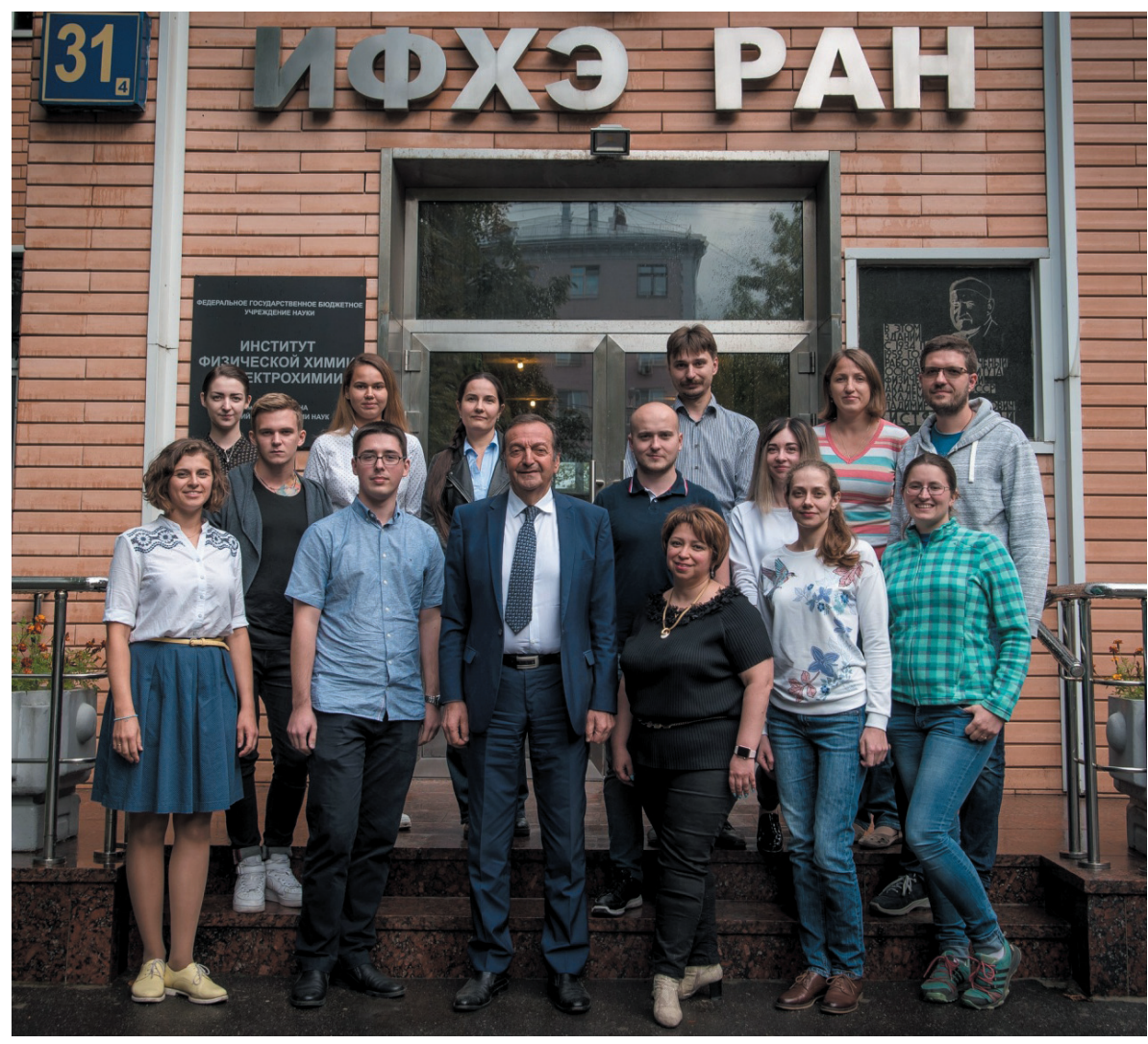

Figure 33. The team of young researchers working under the leadership of Prof. Aslan Yu. Tsivadze (September 2017).

\section{References}

1. Koifman O.I., Stuzhin P.A., Gorbunova Y.G. Macroheterocycles 2012, 5, 286-291.

2. Gorbunova Y., Guilard R. J. Porphyrins Phthalocyanines 2014, 18, I-III.

3. Martynov A.G., Birin K.P., Gorbunova Y.G., Tsivadze A.Y. Macroheterocycles 2013, 6, 23-32.

4. Martynov A.G., Mack J., Ngoy B.P., Nyokong T., Gorbunova Y.G., Tsivadze A.Y. Dyes Pigm. 2017, 140, 469-479.

5. Birin K.P., Gorbunova Y.G., Tsivadze A.Y., BessmertnykhLemeune A.G., Guilard R. Eur. J. Org. Chem. 2015, 2015, 5610-5619.

6. Abdulaeva I.A., Birin K.P., Michalak J., Romieu A., Stern C., Bessmertnykh-Lemeune A., Guilard R., Gorbunova Y.G., Tsivadze A.Y. New J. Chem. 2016, 40, 5758-5774.

7. Birin K.P., Gorbunova Y.G., Tsivadze A.Y. RSC $A d v . \mathbf{2 0 1 5}$, 5, 67242-67246.

8. Michalak J., Birin K.P., Muniappan S., Ranyuk E., Enakieva Y.Y., Gorbunova Y.G., Stern C., Bessmertnykh-Lemeune A., Guilard R. J. Porphyrins Phthalocyanines 2014, 18, 35-48.

9. Birin K.P., Chugunov V.N., Krapivenko A.A., Gorbunova Y.G., Tsivadze A.Y. Macroheterocycles 2014, 7, 153-161.

10. Kroitor A.P., Cailler L.P., Martynov A.G., Gorbunova Y.G., Tsivadze A.Y., Sorokin A.B. Dalton Trans. 2017, 46, 1565115655.

11. Polovkova M.A., Martynov A.G., Birin K.P., Nefedov S.E., Gorbunova Y.G., Tsivadze A.Y. Inorg. Chem. 2016, 55, 92589269.

12. Holmberg R.J., Polovkova M.A., Martynov A.G., Gorbunova Y.G., Murugesu M. Dalton Trans. 2016, 45, 9320-9327.

13. Enakieva Y.Y., Michalak J., Abdulaeva I.A., Volostnykh M.V., Stern C., Guilard R., Bessmertnykh-Lemeune A.G., Gorbu- nova Y.G., Tsivadze A.Y., Kadish K.M. Eur. J. Org. Chem. 2016, 2016, 4881-4892.

14. Bessmertnykh-Lemeune A.G., Stern C., Gorbunova Y.G., Tsivadze A.Y., Guilard R. Macroheterocycles 2014, 7, 122-132.

15. Fang Y., Gorbunova Y.G., Chen P., Jiang X., Manowong M., Sinelshchikova A.A., Enakieva Y.Y., Martynov A.G., Tsivadze A.Y., Bessmertnykh-Lemeune A., Stern C., Guilard R., Kadish K.M. Inorg. Chem. 2015, 54, 3501-3512.

16. Zubatyuk R.I., Sinelshchikova A.A., Enakieva Y.Y., Gorbunova Y.G., Tsivadze A.Y., Nefedov S.E., BessmertnykhLemeune A., Guilard R., Shishkin O.V. CrystEngComm 2014, 16, 10428-10438.

17. Sinelshchikova A.A., Nefedov S.E., Enakieva Y.Y., Gorbunova Y.G., Tsivadze A.Y., Kadish K.M., Chen P., Bessmertnykh-Lemeune A., Stern C., Guilard R. Inorg. Chem. 2013, 52, 999-1008.

18. Uvarova M.A., Sinelshchikova A.A., Golubnichaya M.A., Nefedov S.E., Enakieva Y.Y., Gorbunova Y.G., Tsivadze A.Y., Stern C., Bessmertnykh-Lemeune A., Guilard R. Cryst. Growth Des. 2014, 14, 5976-5984.

19. Enakieva Y.Y., Volostnykh M.V., Nefedov S.E., Kirakosyan G.A., Gorbunova Y.G., Tsivadze A.Y., Bessmertnykh-Lemeune A.G., Stern C., Guilard R. Inorg. Chem. 2017, 56, 3055-3070.

20. Martynov A.G., Gorbunova Y.G., Tsivadze A.Y. Russ. J. Inorg. Chem. 2014, 59, 1635-1664.

21. Martynov A.G., Panova M.V., Gorbunova Y.G., Tsivadze A.Y. Macroheterocycles 2014, 7, 47-54.

22. Lapkina L.A., Larchenko V.E., Kirakosyan G.A., Tsivadze A.Y., Troyanov S.I., Gorbunova Y.G. Inorg. Chem. 2018, $57,82-88$.

23. Lapkina L.A., Gorbunova Y.G., Gil D.O., Ivanov V.K., Konstantinov N.Y., Tsivadze A.Y. J. Porphyrins Phthalocyanines 2013, 17, 564-572. 
24. Safonova E.A., Martynov A.G., Zolotarevskii V.I., Nefedov S.E., Gorbunova Y.G., Tsivadze A.Y. Dalton Trans. 2015, 44, 1366-1378.

25. Mack J., Mkhize S., Safonova E.A., Martynov A.G., Gorbunova Y.G., Tsivadze A.Y., Nyokong T. J. Porphyrins Phthalocyanines 2016, 20, 505-513.

26. Safonova E.A., Martynov A.G., Nefedov S.E., Kirakosyan G.A., Gorbunova Y.G., Tsivadze A.Y. Inorg. Chem. 2016, $55,2450-2459$.

27. Nefedova I.V., Martynov A.G., Averin A.A., Kirakosyan G.A., Tsivadze A.Y., Gorbunova Y.G. Isr. J. Chem. 2016, 56, 181-187.

28. Meshkov I.N., Bulach V., Gorbunova Y.G., Kyritsakas N., Grigoriev M.S., Tsivadze A.Y., Hosseini M.W. Inorg. Chem. 2016, 55, 10774-10782.

29. Birin K.P., Poddubnaya A.I., Isanbaeva E.V., Gorbunova Y.G., Tsivadze A.Y.J. Porphyrins Phthalocyanines 2017, 21, 406-415.

30. Selektor S.L., Shokurov A.V., Arslanov V.V., Gorbunova Y.G., Birin K.P., Raitman O.A., Morote F., Cohen-Bouhacina T., Grauby-Heywang C., Tsivadze A.Y. J. Phys. Chem. C 2014, $118,4250-4258$.

31. Britton J., Martynov A.G., Oluwole D.O., Gorbunova Y.G., Tsivadze A.Y., Nyokong T. J. Porphyrins Phthalocyanines 2016, 20, 1296-1305.

32. Oluwole D.O., Yagodin A.V., Mkhize N.C., Sekhosana K.E., Martynov A.G., Gorbunova Y.G., Tsivadze A.Y., Nyokong T. Chem. Eur. J. 2017, 23, 2820-2830.

33. Oluwole D.O., Yagodin A.V., Britton J., Martynov A.G., Gorbunova Y.G., Tsivadze A.Y., Nyokong T. Dalton Trans. 2017, 46, 16190-16198.

34. Gorbunova Y.G., Grishina A.D., Martynov A.G., Krivenko T.V., Isakova A.A., Savel'ev V.V., Nefedov S.E., Abkhalimov E.V., Vannikov A.V., Tsivadze A.Y. J. Mater. Chem. C 2015, 3, 6692-6700.

35. Sokolov V.S., Gavrilchik A.N., Kulagina A.O., Meshkov I.N., Pohl P., Gorbunova Y.G. J. Photochem. Photobiol. B Biol. 2016, 161, 162-169.

36. Meshkov I.N., Bulach V., Gorbunova Y.G., Gostev F.E., Nadtochenko V.A., Tsivadze A.Y., Hosseini M.W. Chem. Commun. 2017, 53, 9918-9921.
37. Fang Y., Kadish K.M., Chen P., Gorbunova Y., Enakieva Y., Tsivadze A., Bessmertnykh-Lemeune A., Guilard R. J. Porphyrins Phthalocyanines 2013, 17, 1035-1045.

38. Stern C., Bessmertnykh-Lemeune A.G., Gorbunova Y.G., Tsivadze A.Y., Guilard R. Turk. J. Chem. 2014, 38, 980993.

39. Selektor S.L., Shokurov A.V., Revina A.A., Arslanov V.V., Gorbunova Y.G., Tsivadze A.Y. Macroheterocycles 2015, 8, 135-142.

40. Vannikov A.V., Grishina A.D., Gorbunova Y.G., Tsivadze A.Y. Org. Photonics Photovoltaics 2015, 3.

41. Lemeune A., Mitrofanov A.Y., Rousselin Y., Stern C., Guilard R., Enakieva Y.Y., Gorbunova Y.G., Nefedov S.E. Phosphorus Sulfur Silicon Relat. Elem. 2015, 190, 831-836.

42. Ermakova E.V., Enakieva Y.Y., Zvyagina A.I., Gorbunova Y.G., Kalinina M.A., Arslanov V.V. Macroheterocycles 2016, 9, 378-386.

43. Bessmertnykh-Lemeune A.G., Guilard R., Stern C., Enakieva Y.Y., Gorbunova Y.G., Tsivadze A.Y., Nefedov S.E. Biomimetic Studies of Porphyrin Self-Assembled Systems. In: Supramolecular Systems: Chemistry, Types and Applications (Pena C.. Ed.). Nova Science Publisher, 2016, pp. 213278.

44. Zvyagina A.I., Meshkov I.N., Ezhov A.A., Shiryaev A., Gorbunova Y.G., Birin K.P., Tsivadze A.Y., Arslanov V.V., Kalinina M.A. Colloids Surf., A 2016, 509, 376-383.

45. Ermakova E.V., Meshkov I.N., Enakieva Yu.Y., Zvyagina A.I., Ezhov A.A., Mikhaylov A.A., Gorbunova Y.G., Chernyshev V.V., Kalinina M.A., Arslanov V.V. Surf. Sci. 2017, 660, 39-46.

46. Zvyagina A.I., Shiryaev A.A., Baranchikov A.E., Chernyshev V.V., Enakieva Y.Y., Raitman O.A., Ezhov A.A., Meshkov I.N., Grishanov D.A., Ivanova O.S., Gorbunova Y.G., Arslanov V.V., Kalinina M.A. New J. Chem. 2017, 41, 948957.

47. Gorbunova Y.G., Martynov A.G., Tsivadze A.Y. Crown-Substituted Phthalocyanines: From Synthesis towards Materials. In: Handbook of Porphyrin Science, Vol. 24 (Kadish K.M., Smith K.M., Guilard R., Eds.). World Scientific Publishing, 2012, pp. 271-388. 